\title{
Attempted Predation by Peregrine Falcons
}

\author{
by E. Kuyt, Canadian Wildlife Service, Fort Smith, N.W.T.
}

While I was hunting ducks on the Hudson Bay sloughs near the Salt Plains Buffalo corral, about 15 miles northwest of Fort Smith, N.W.T., cn September 7, 1963, I spotted six Mallards feeding along the border of a pond and attempted to creep up on them. I had come almost within range when a flock cf Common Grackles, previously feeding on the muddy shore of the pond, noisily flew to the nearby bushes. I looked up just in time to see an adult female Peregrine Falcon (Falco peregrinus) swoop low over the ducks, pull up out of the dive and circle back for another attempt. I straightened up slowly to watch the falcon and the ducks' reaction to it. The Mallards saw me, however, and with the falcon still climbing and thus cut of position, the ducks flushed, leaving me no chance to shoot. The falcon, also alarmed at my presence, did not continue the chase.

On September 30 I was duck hunting near the Embarrass River, about ten miles south of Fcrt Chipewyan, Alberta. During a lull in the movements of the ducks, a juvenile Peregrine Falcon stooped at a flock of unidentified small sandpipers feeding in a shallow part of a large pcnd. The shorebirds flew up "en masse" but quickly landed when the falcon turned for another pass. One sandpiper did not land but elected to go aloft. I expected that this bird would be quickly struck down by the predator, but, to my surprise, however, a long chase ensued. The Peregrine executed a series of short bursts, quickly gaining on its intended prey, then invariably shooting past its quarry which showed a remarkable adeptness at evasive action. At least 20 of these passes were witnessed. The falcon made climbing passes as well as downward stoops and the latter appeared to cause the sandpiper the greatest difficulties. I received the impression that the chase might go on indefinitely as falcon and sandpiper appeared evenly matched. The chase went higher and higher and downwind from my position until I first lost the "peep" from view and then the falcon, and I was unable to determine the outcome of the contest.
Even though an adult Peregrine might have done "better" than the juvenile bird, certainly the sandpiper was no "push-over". The sandpiper was well able to take care of itself when pitted against its natural enemy.

Ed. Note: Interested persons may wish to read two reports of similar observaticns published in the September, 1958, Blue Jay, p. 114. There is also an article on predation in the present issue (p. 31) in which Wayne Miller, Brandon, tells of a Marsh Hawk attacking a coot.

\section{PRAIRIE NEST RECORDS SCHEME}

The March issue of The Blue Jay has regularly carried the annual report of the PNRS. This year the report will appear in the June issue. Meanwhile, Bob Taylor, the new convener of scheme, wishes to urge all members interested in submitting 1964 nest records to write to him for cards and further instructions about keeping records. Thcse who contributed records in 1963 will receive cards automatically. Those who did not ccntribute in 1963 and who are writing for 1964 cards should try tc indicate how many cards are needed. Write:

Robert R. Taylor,

Prairie Nest Records Scheme, Blue Jay, Box 1121, Regina, Sask.

\section{CO-OPERATIVE SPRING} MIGRATION STUDY

Reccrds are again requested for the continent-wide survey being made under the auspices of the U.S. Fish and Wildlife Service. As socn as it is available, we shall have a list of species for which reports are wanted; please write for the list and then submit your records by June 15,1964 , to:

\section{Co-operative Spring Migration Study \\ Blue Jay, Box 1121,} Regina, Sask. 